\title{
Functional ecology of the biological soil crust in semiarid SE Spain: sun and shade populations of Diploschistes diacapsis (Ach.) Lumbsch.
}

\author{
Ana PINTADO, Leopoldo G. SANCHO, T. G. Allan GREEN, \\ José Manuel BLANQUER and Roberto LÁZARO
}

\begin{abstract}
The Tabernas badlands in semiarid south-east Spain is one of the driest regions in Europe with a mean annual precipitation of $c .240 \mathrm{~mm}$. The landscape is deeply dissected, with canyons, ramblas and sparsely vegetated eroded badland slopes. The vegetation is predominantly a biological soil crust consisting of different types of lichen-rich communities, one of the more conspicuous being dominated by Diploschistes diacapsis (Ach.) Lumbsch. This lichen is mainly restricted to the northfacing slopes, where it forms extensive whitish carpets and probably plays an important role in preventing erosion of the slopes and allowing plant colonization. South-facing slopes are much more eroded and generally lack vegetation.

The photosynthetic performance of north (shade) and south-facing (sun) populations of $D$. diacapsis was studied to determine if these different populations showed any adaptations to the microclimatic conditions of their individual habitats. The response of $\mathrm{CO}_{2}$ exchange to light intensity, temperature and water content was measured under controlled conditions in the laboratory. Dry weight-based net photosynthetic rates were higher in the southern-exposed population but quantum efficiency, and light compensation points were similar. Thallus weight per unit area (LMA) was considerably higher for shade specimens but maximum water content and optimal water content were very similar and chlorophyll content on a dry weight basis was also similar. Chlorophyll content on an area basis was higher in the northern-exposed population and always much larger than those reported in other studies on the same species (up to 8 times larger) with the result that NP values on a chlorophyll basis were relatively low. The larger LMA meant that shade thalli stored more water per unit area which should ensure longer active periods than sun thalli. The results support a strategy pair of high NP and short active time versus low NP and long active time, both having been reported for other soil crust species. However, the visibly larger biomass of the shade $D$. diacapsis suggests that the lichen is at the limit of its adaptability in these habitats.
\end{abstract}

Key words: Diploschistes diacapsis, ecophysiology, semiarid south-east Spain, soil crust

\section{Introduction}

The Tabernas badlands in semiarid southeast Spain (latitude $37 \cdot 0^{\circ} \mathrm{N}$, longitude $\left.2 \cdot 4^{\circ} \mathrm{W}\right)$ is one of the driest regions in Europe. The mean annual precipitation is

A. Pintado (corresponding author), L. G. Sancho and J. M. Blanquer: Departamento de Biologia Vegetal II, Facultad de Farmacia, Universidad Complutense, Plaza de Ramon y Cajal s/n, 28040 Madrid, Spain.

A. Pintado and R. Lázaro: Estación Experimental de Zonas Áridas, CSIC, c/ General Segura 1, 04001 Almeria, Spain.

T. G. A. Green: Biological Sciences, Waikato University, Hamilton, New Zealand. around $240 \mathrm{~mm}$ (Lazaro et al. 2001). The landscape is deeply dissected, with canyons, ramblas and sparsely vegetated, eroded badland slopes. The most common vegetation type is a biological soil crust that consists of different types of lichen-dominated communities (Alexander \& Calvo 1990). Soil crust communities are known to play an important role in the functioning of arid ecosystems (Belnap et al. 2003). Area-related photosynthetic parameters, chlorophyll content and net photosynthesis can reach levels approaching $\mathrm{C} 3$ crop plants and, with the crust communities covering large areas, carbon inputs can be important (Lange et al. 1997). 
The crusts are also extremely important because of their influence on the hydrological cycle and soil stability through their effects on rain interception, water infiltration, surface evaporation and moisture storage (Alexander \& Calvo 1990; Calvo-Cases et al. 1991; Alexander et al. 1994; Solé-Benet et al. 1997; Mottershead \& Lucas 2000; George et al. 2003). Interest in soil crusts has grown considerably recently as their importance in the functioning of arid ecosystems has increasingly been recognized (St. Clair \& Johansen 1993; Belnap \& Lange 2003). In the Tabernas badlands one of the more conspicuous communities is dominated by Diploschistes diacapsis (Ach.) Lumbsch, a species already known to be important in other areas (Lange et al. 1997). Slope orientation strongly influences microclimatic conditions and vegetation cover and the $D$. diacapsis community is mainly restricted to the north-facing slopes and pediments, where it forms extensive whitish carpets that appear to play an important role in preventing erosion of these slopes and allowing plant colonization (Alexander et al. 1994). By contrast, south-facing slopes lack vegetation and are much more eroded. A fragmentary micropediment occasionally remains at the bottom of such slopes which supports other terricolous crustose lichens together with sparse thalli of $D$. diacapsis that appear in the contact area between the slopes and the micropediments. At present little is known about the performance of this species in this very dry site in comparison to other ecosystems. We do not know if the lichen possesses physiological or morphological adaptations particular to these two habitats or whether its low coverage on the south-facing slopes is a result of limits to its capacity for further morphological and photosynthetic change.

In an initial approach to answering these questions we have determined the $\mathrm{CO}_{2}$ exchange response to light intensity, temperature and water content under controlled conditions in the laboratory of samples from the north- and south-facing populations of $D$. diacapsis. Thallus structure was also investigated to assist interpretations of any physiological differences found between the two populations.

\section{Materials and Methods}

\section{Species and site description}

Diploschistes diacapsis (Ach.) Lumbsch is a terricolous crustose, verrucosely areolate, 1-3 mm thick lichen with urceolate apothecia and white pruina (Lumbsch 1988). Its distribution is northern xeric occurring on calcareous and gypsaceous soils in exposed habitats (Llimona 1973; Gutiérrez \& Casares 1994). Samples of D. diacapsis were collected on gypsiferous marls from north- and south-facing slopes in the semi-arid habitat of El Cautivo, Tabernas desert (Almería, south-east Spain, latitude $37 \cdot 0^{\circ} \mathrm{N}$, longitude $\left.2 \cdot 4^{\circ} \mathrm{W}\right)$. This badland site has been extensively described by Alexander et al. (1994) and Lazaro et al. (2000). On the northfacing slopes, D. diacapsis forms a continuous, thick whitish crust together with other species, principally Squamarina lentigera (Weber) Poelt. We designated samples from these sites as the 'shade' population, because they benefit from the slope shadow for most of the day. On the south-facing slopes, thalli were much smaller, sparsely distributed and were exposed to sun nearly all day; these we called the 'sun' population. After collection, dry samples were transported to the laboratory at the Universidad Complutense de Madrid and used immediately.

\section{Gas exchange, water content and chlorophyll measurements}

Gas exchange measurements were carried out using an open flow system (Compact Minicuvette System CMS400, Walz, Germany) operated under controlled light and temperature. Lichens were initially reactivated for three days in a chamber at $15^{\circ} \mathrm{C}$ under a $12: 12 \mathrm{~h}$ photoperiod and photosynthetic photon fluence rate (PPFR) measured over the waveband $400-700 \mathrm{~nm}$ of c. $100 \mu \mathrm{mol} \mathrm{m}^{-2} \mathrm{~s}^{-1}$. They were kept moist by spraying with water once a day. Six samples from each exposure were divided into two sets of three samples and their $\mathrm{CO}_{2}$ exchange measured under different combinations of light $(0,25,50,100,200,400,800$, $1200 \mu \mathrm{mol} \mathrm{m} \mathrm{m}^{-2} \mathrm{~s}^{-1}$ PPFR) and temperature (set 1 at $0,5,10$ and $15^{\circ} \mathrm{C}$; set 2 at $15,20,25$ and $30^{\circ} \mathrm{C}$ ) at thallus water contents that were optimal for net photosynthesis. Two sets of thalli were used because of the long periods required to complete the measurements. Optimal water content (OWC) for net photosynthesis was determined before these measurements by wetting samples to maximal water content (MWC, submerged in water for 30 minutes followed by gently shaking), enclosing them in a cuvette, and recording $\mathrm{CO}_{2}$ exchange as they slowly dried at a PPFR of $400 \mu \mathrm{mol} \mathrm{m}^{-2}$ $\mathrm{s}^{-1}$ and $15^{\circ} \mathrm{C}$. Thalli were weighed at intervals whilst drying and also before and after measurements at the different temperature and PPFR combinations.

After the gas exchange measurements, surface areas of the samples were measured using SIGMASCAN 
PRO5 and total chlorophyll contents $(\mathrm{Chl} a+b)$ were determined on a subsample after washing with $\mathrm{CaCO}_{3}{ }^{-}$ saturated $100 \%$ acetone and extraction with $\mathrm{CaCO}_{3}$ saturated DMSO (Barnes et al. 1992). Absorbance of chlorophyll $a+b$ was determined by means of a UVIKON XL spectrophotometer (Secomam, France). The thallus water content was calculated from the weights recorded during the measurements and from the dry weight obtained by drying a subsample for 24 hours at $103^{\circ} \mathrm{C}$. Net photosynthesis (NP), dark respiration (DR) as well as the calculated gross photosynthesis $(\mathrm{GP}=\mathrm{NP}+\mathrm{DR})$ of the samples were related to thallus dry weight, thallus area and total chlorophyll content. The parameters PPFR $_{\text {sat }}$ (light intensity necessary to achieve $95 \%$ of maximal NP) and LCP (light compensation point) were obtained from fitted light curves using SIGMAPLOT 8.0. Maximal quantum efficiency of $\mathrm{CO}_{2}$-fixation was determined as the slope of the NP (area basis) to PPFR response curve between 0 and $50 \mu \mathrm{mol} \mathrm{m} \mathrm{m}^{-2} \mathrm{~s}^{-1}$.

\section{Measurements of thallus structure}

Thickness of the thallus was measured for five sections of each dry thallus with a calibrated binocular microscope. The thickness of the photobiont layer, the upper cortex and the medulla was measured from 10 transverse sections cut from each fully hydrated thallus using a Slee MTC (Germany) cryostat. Sections (15 $\mu \mathrm{m}$ thick) were stained with lactophenol cotton blue and measurements were made using a calibrated eyepiece micrometer.

\section{Results}

\section{$\mathrm{CO}_{2}$ exchange}

Both sun and shade populations showed an expected and typical saturation-type response of NP to PPFR (Fig. 1) that was substantially affected by ambient temperature. PPFR $_{\text {sat }}$ values (light intensity necessary to achieve $95 \%$ of maximal NP) increased with temperature in both populations from around $400 \mu \mathrm{mol} \mathrm{m} \mathrm{m}^{-2} \mathrm{~s}^{-1}$ at $0^{\circ} \mathrm{C}$, to no saturation at $1200 \mu \mathrm{mol} \mathrm{m} \mathrm{m}^{-2}$ $\mathrm{s}^{-1}$ (the highest PPFR used) above $15^{\circ} \mathrm{C}$. At temperatures below $15^{\circ} \mathrm{C}, \mathrm{PPFR}_{\mathrm{sat}}$ values were higher for the sun population with the most notable differences being at $5^{\circ} \mathrm{C}\left(480 \mu \mathrm{mol} \mathrm{m} \mathrm{m}^{-2} \mathrm{~s}^{-1}\right.$ for the shade samples and $640 \mu \mathrm{mol} \mathrm{m}{ }^{-2} \mathrm{~s}^{-1}$ for the sun samples). However, at 20 and $25^{\circ} \mathrm{C}$, whilst $\mathrm{NP}$ of the northern-exposed, shade thalli were almost saturated at $800 \mu \mathrm{mol} \mathrm{m} \mathrm{m}^{-2}$ $\mathrm{s}^{-1}$, NP of the southern-exposed, sun thalli were still clearly increasing.

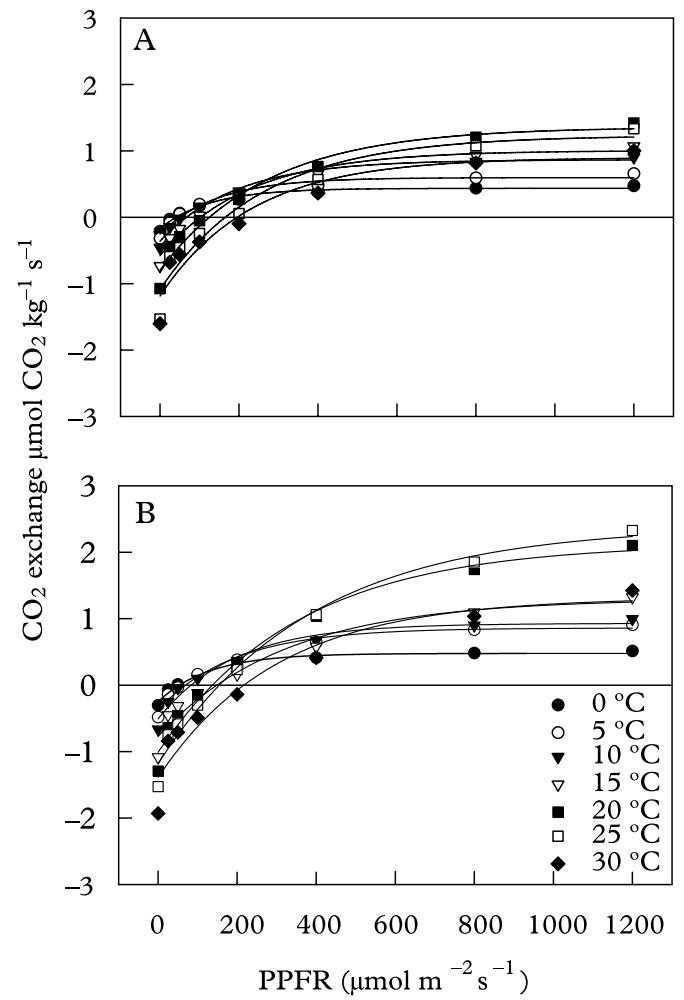

FIG. 1. $\mathrm{CO}_{2}$ exchange response (related to thallus dry weight) in Diploschistes diacapsis to incident photosynthetic photon fluence rate (PPFR) at different temperatures and optimal water content. A, northern-exposed thalli (shade population); B, southern-exposed thalli (sun population). Each point is the average of three samples; $r>0.97$ for all regressions.

Light compensation points of $\mathrm{CO}_{2}$ exchange (LCP) increased with temperature in thalli from both exposures, a change driven by the high temperature response of respiration, and tended to be slightly higher for the sun population (Fig. 2A). Values ranged from $54 \mu \mathrm{mol} \mathrm{m}^{-2} \mathrm{~s}^{-1}$ at $0^{\circ} \mathrm{C}$ to $218 \mu \mathrm{mol}$ $\mathrm{m}^{-2} \mathrm{~s}^{-1}$ at $30^{\circ} \mathrm{C}$ for the sun samples compared to 41 to $196 \mu \mathrm{mol} \mathrm{m} \mathrm{m}^{-2} \mathrm{~s}^{-1}$ for the shade samples over the same temperature range. Maximal apparent quantum efficiency for $\mathrm{CO}_{2}$-exchange, calculated as the slope of the response of net photosynthesis to PPFR up to $50 \mu \mathrm{mol} \mathrm{m} \mathrm{m}^{-2} \mathrm{~s}^{-1}$, also showed little difference between the two forms. Values increased with temperature 

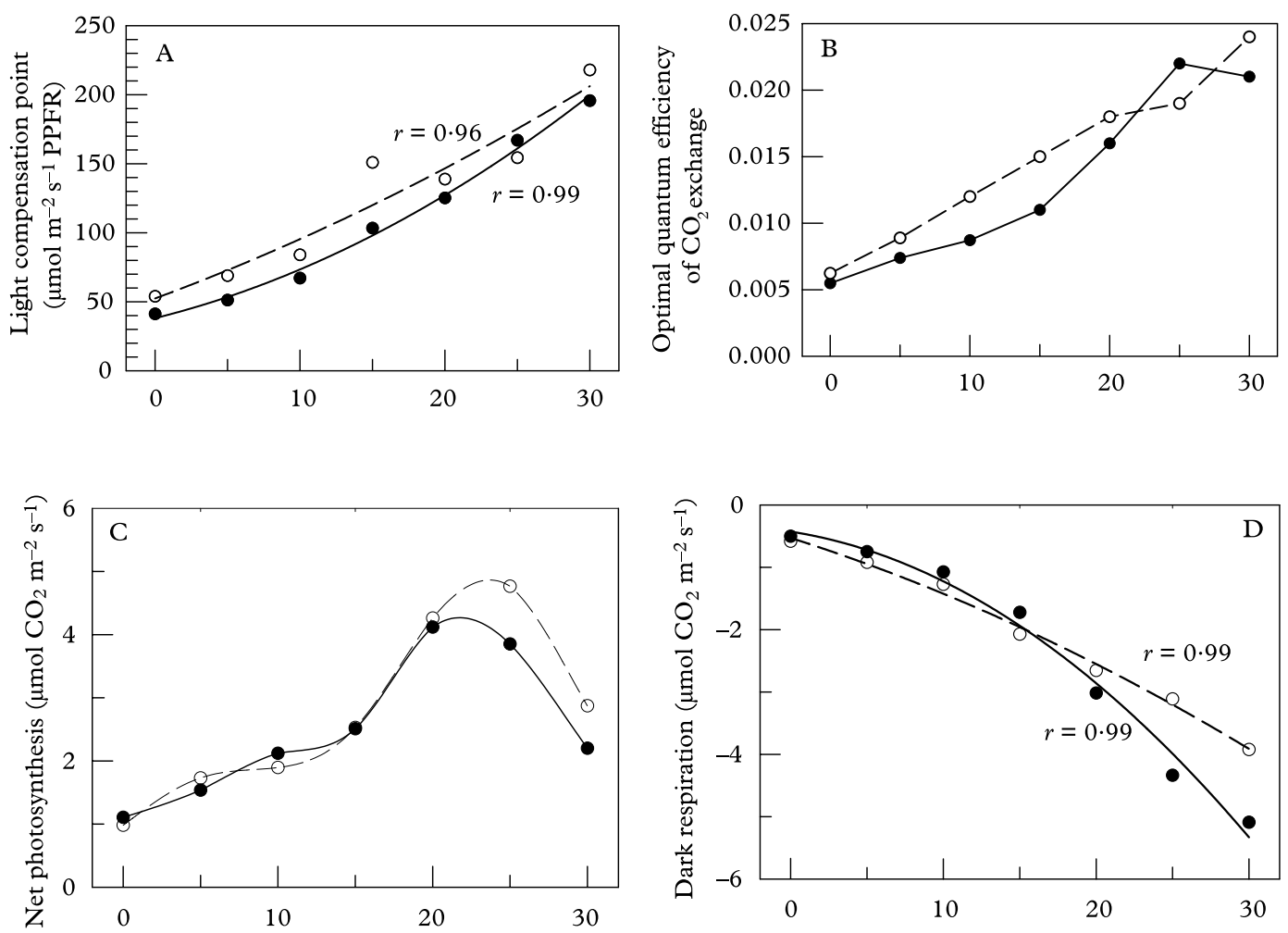

Temperature $\left({ }^{\circ} \mathrm{C}\right)$

FIG. 2. The effect of thallus temperature on photosynthesis and respiration in sun $(\bigcirc)$ and shade $(0)$ populations of Diploschistes diacapsis. A, response of light compensation point of net $\mathrm{CO}_{2}$ exchange (obtained from regression curves of NP response to PPFR); B, response of optimal quantum use efficiency (calculated from linear regressions of NP response to PPFR from $0-50 \mu \mathrm{mol} \mathrm{m}{ }^{-2} \mathrm{~s}^{-1}$ ); C, response of maximal net photosynthesis (NP max. area basis, highest measured rates at $1200 \mu \mathrm{mol} \mathrm{m} \mathrm{m}^{-2} \mathrm{~s}^{-1}$ PPFR and optimal water content), each point being the average of three samples; D, response of maximal dark respiration (DR max area basis, highest measured rates at high water content), each point the average of six samples.

from 0.005 at $0^{\circ} \mathrm{C}$ to 0.024 at 25 and $30^{\circ} \mathrm{C}$ (Fig. 2B).

Maximal rates of net photosynthesis (NP max DW basis, Table 1) were much higher in sun thalli reaching $2.45 \mu \mathrm{mol} \mathrm{kg}^{-1} \mathrm{~s}^{-1}$ (c. $72 \%$ higher) compared to $1 \cdot 42 \mu \mathrm{mol}$ $\mathrm{kg}^{-1} \mathrm{~s}^{-1}$; the difference was similar ( $c$. $70 \%$ ) on a chlorophyll basis. Maximal net photosynthetic rates (area basis) were identical for the sun and shade forms up to almost $20^{\circ} \mathrm{C}$. The shade form then reached a maximum at $21.8^{\circ} \mathrm{C}$ whilst the sun form continued to rise until its slightly higher maximum at $23.8^{\circ} \mathrm{C}$ (Fig. 2C). Dark respiration increased similarly with temperature for thalli from both exposures although the shade thalli had increasingly greater DR (area basis) above $20^{\circ} \mathrm{C}$ (Fig. 2D). Gross photosynthetic rates (area basis) were almost identical with both forms reaching maximal values at just below $25^{\circ} \mathrm{C}$.

No differences were found between the two forms in the response of net photosynthesis to degree of thallus hydration (Fig. 3) with net photosynthesis being highly suppressed at high water contents in both populations. Optimal water content for net photosynthesis was slightly higher in shade forms $(49 \cdot 7 \%$ against $41 \cdot 3 \%$ of maximum relative water content of $27 \cdot 6 \%$ against $24.4 \%$ on a dry weight basis, Table 1). 
TABLE 1. Some ecophysiological parameters for shade (northern-exposed) and sun (southern-exposed) thalli of Diploschistes diacapsis. For NP max and Dark respiration values n=3; for Chlorophyll content, Maximal water content and Optimal water content $\mathrm{n}=6$

\begin{tabular}{|c|c|c|}
\hline & $\begin{array}{c}\text { Shade } \\
\text { (Northern-exposed) }\end{array}$ & $\begin{array}{c}\text { Sun } \\
\text { (Southern-exposed) }\end{array}$ \\
\hline NP max - dry weight basis $\left(\mu \mathrm{mol} \mathrm{CO} \mathrm{Cg}^{-1} \mathrm{~s}^{-1}\right)$ & $1 \cdot 42 \pm 0 \cdot 22^{\star}$ & $2 \cdot 45 \pm 0 \cdot 14^{\star}$ \\
\hline $\mathrm{NP} \max$ - chlorophyll basis $\left(\mathrm{mg} \mathrm{CO}_{2} \mathrm{mg}^{-1} \mathrm{~h}^{-1}\right)$ & $0 \cdot 33 \pm 0 \cdot 05^{\star}$ & $0 \cdot 56 \pm 0 \cdot 01^{\star}$ \\
\hline $\mathrm{NP} \max$ - area basis $\left(\mu \mathrm{mol} \mathrm{CO} \mathrm{m}^{-2} \mathrm{~s}^{-1}\right)$ & $4 \cdot 13 \pm 1 \cdot 10$ & $5 \cdot 00 \pm 0 \cdot 67$ \\
\hline Dark respiration-dry weight basis $\left(\mu \mathrm{mol} \mathrm{CO}_{2} \mathrm{~kg}^{-1} \mathrm{~s}^{-1}\right)$ & $1 \cdot 80 \pm 0 \cdot 39$ & $1.93 \pm 0.62$ \\
\hline Chlorophyll content - dry weight basis (mg Chl $a+b \mathrm{~g}^{-1}$ ) & $0.68 \pm 0.07$ & $0 \cdot 68 \pm 0.04$ \\
\hline Chlorophyll content - area basis (mg Chl $a+b \mathrm{~m}^{-2}$ ) & $1780 \pm 340^{\star}$ & $1350 \pm 200^{\star}$ \\
\hline Maximal water content (\% of dry weight) & $56 \cdot 0 \pm 6 \cdot 83$ & $59 \cdot 7 \pm 5 \cdot 71$ \\
\hline Optimal water content ( $\%$ of dry weight) & $27 \cdot 6 \pm 4 \cdot 27$ & $24 \cdot 4 \pm 7 \cdot 41$ \\
\hline
\end{tabular}

^differences significant (ANOVA, 1.s.d., P<0.05).

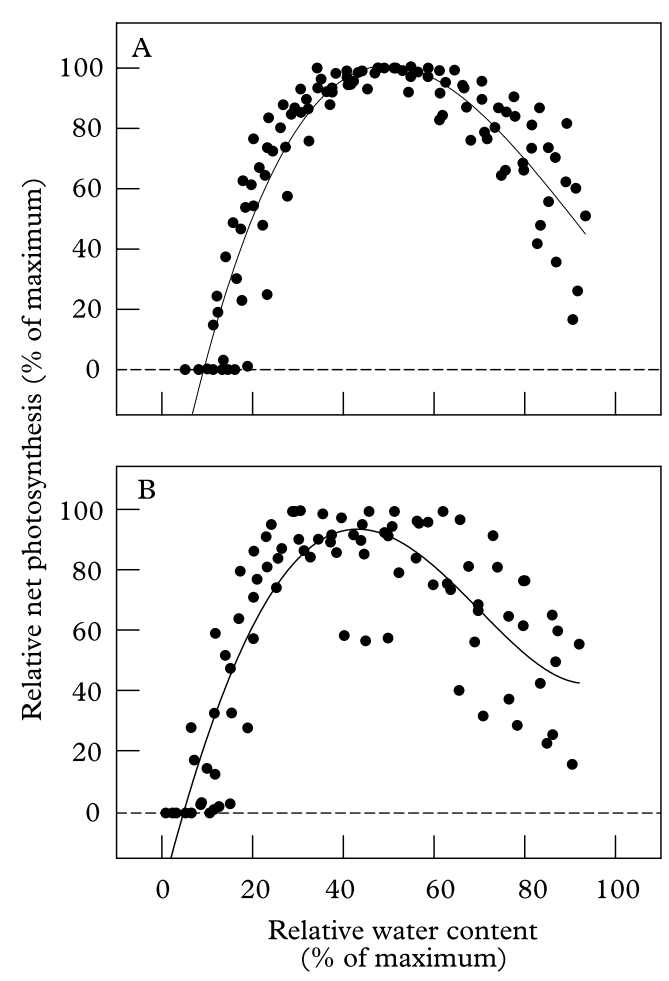

FIG. 3. The dependence of net photosynthesis on thallus water content in Diploschistes diacapsis. A, northernexposed thalli (shade population); B, southern-exposed thalli (sun population). Points represent measurements of 6 thalli from each population at $400 \mu \mathrm{mol} \mathrm{m} \mathrm{m}^{-2} \mathrm{~s}^{-1}$ and $15^{\circ} \mathrm{C}$.

\section{Thallus morphology and chlorophyll content}

Shade thalli were considerably and significantly $(P<0.05)$ thicker than sun forms: $1.77 \mathrm{~mm}$ and $1.06 \mathrm{~mm}$, respectively (Table 2). One consequence was that shade thalli had a much larger mass to area ratio (LMA) of 0.261 versus $0.198 \mathrm{~g} \mathrm{~cm}^{-2}$ but were less dense, 1.48 against $1.90 \mathrm{~g} \mathrm{ml}^{-1}$. Internally, the upper cortices were identical in thickness $(50.7$ and $51 \cdot 1 \mu \mathrm{m}$ for shade and sun, respectively), but the algal layer was much thicker in the shade thalli $(85.5 \mathrm{v} .63 .6 \mu \mathrm{m}$, $P<0 \cdot 05)$. Shade and sun forms had identical total chlorophyll contents on a dry weight basis (Chl $a+b, 0.68 \mathrm{mg} \mathrm{g}^{-1}$, Table 1 ) but, because of the different LMA of the two forms, the shade thalli had a much higher chlorophyll content on an area basis, 1780 against $1350 \mathrm{mg} \mathrm{m}^{-2}$ for the sun forms. However, the total chlorophyll was spread through a thicker algal layer in the shade thalli with the result that chlorophyll density was identical for both forms at $0.21 \mathrm{ng}$ $\mathrm{ml}^{-1}$. Maximal thallus water contents (MWC) were also very similar, $56.0 \%$ and $59.7 \%$ in shade and sun thalli, respectively (Table 1). However, the larger LMA for the shade thalli meant that they stored more water (on an area basis) than the sun forms, 0.146 versus $0.118 \mathrm{~g} \mathrm{~cm}^{-2}$, or 1.46 and $1.18 \mathrm{~mm}$ precipitation equivalent respectively, $24 \%$ more. 
TABLE 2. Structural parameters for shade (northern-exposed) and sun (southern-exposed) thalli of Diploschistes diacapsis. Mean values are given $\pm I S E M$ (for $\mathrm{n}$ values see methods)

\begin{tabular}{lcc}
\hline & $\begin{array}{c}\text { Shade } \\
\text { (Northern-exposed) }\end{array}$ & $\begin{array}{c}\text { Sun } \\
\text { (Southern-exposed) }\end{array}$ \\
\hline Thallus thickness $(\mathrm{mm})$ & $1 \cdot 77 \pm 0 \cdot 35^{\star}$ & $1 \cdot 06 \pm 0 \cdot 04^{\star}$ \\
Cortex thickness $(\mu \mathrm{m})$ & $50 \cdot 7 \pm 16 \cdot 5$ & $51 \cdot 1 \pm 15 \cdot 6$ \\
Algal layer thickness $(\mu \mathrm{m})$ & $85 \cdot 5 \pm 5 \cdot 02^{\star}$ & $63 \cdot 6 \pm 14 \cdot 0^{\star}$ \\
Lichen mass to area ratio $\left(\mathrm{g} \mathrm{cm}^{-2}\right)$ & $0 \cdot 26 \pm 0 \cdot 04^{\star}$ & $0 \cdot 19 \pm 0 \cdot 02^{\star}$ \\
Thallus density $\left(\mathrm{g} \mathrm{ml}^{-1}\right)$ & $1 \cdot 48 \pm 0 \cdot 41$ & $1 \cdot 90 \pm 0 \cdot 22$ \\
\hline
\end{tabular}

^Indicates significant differences (ANOVA, 1.s.d., $P<0 \cdot 05$ ).

\section{Discussion}

Perhaps the first reaction to the comparison of the $\mathrm{CO}_{2}$-exchange of the two forms of D. diacapsis was that they appeared to be very similar. Maximum water contents, total chlorophyll content on a weight basis, apparent quantum efficiency, gross photosynthesis (area basis) and optimal temperature for GP are practically identical. However, a closer analysis reveals differences that can be considered to be adaptive to the north and south facing sites in the harsh, arid environment of the Tabernas badlands of Almería. The sun form always had a higher NP, 70\% higher on chlorophyll and dry weight bases and 20\% higher on an area basis. It also has a thinner thallus and considerably less dry matter per unit area, an LMA of $0 \cdot 198$ compared to $0.261 \mathrm{~g} \mathrm{~cm}^{-2}$ for the shade thalli. Even though the maximum thallus water contents (dry weight basis) of the two forms were identical the shade form stored about $24 \%$ more water on an area basis, 1.46 versus $1 \cdot 18 \mathrm{~mm}$ precipitation equivalent. This will translate into considerably longer hydrated periods for the shade form because of the lower drying rates in the shade environment where the lichens are shaded for much of the day.

The two forms appear to have different strategies, extended wetted periods but lower net photosynthetic rates for the shade form, and shorter active periods but higher NP for the thalli in the sun on the southfacing slopes. The same conclusion was obtained by Pintado et al. 1997 when comparing north and south facing populations of
Ramalina capitata. Studies on the same species together with other lichens in a soil crust community in the southern Utah arid desert led Lange et al. (1997) to suggest that the same two strategies also occurred but possessed by different species. A comparison between the photosynthetic abilities of $D$. diacapsis in Almería and in Utah also shows similarities and differences (Table 3). Diploschistes diacapsis from Utah seems to have a lower photosynthetic rate on an area basis but much higher on a chlorophyll basis. This reflects the very high chlorophyll contents found in the Almería samples, six to eight times higher on an area basis and reaching those reported for C3 leaves (Larcher 1995). With such high chlorophyll contents it is not surprising that NP on a chlorophyll basis was much lower for the Almería specimens. Both the MWC and OWC (56\% and 27\% DW basis) of $D$. diacapsis from Almería were remarkably low compared to lichens generally. This could be a consequence of the presence of a very compact and dense upper cortex and a hydrophobic medulla (see figures in Souza-Egipsy et al. 2002). The MWC (area basis) of D. diacapsis from Utah are higher than those from Almería and this would suggest a potential for longer active periods for the former. This is probably a reflection of the better dispersed rainfall of the Utah desert. Again, the rule seems to be, longer wet periods with lower maximal net photosynthetic rates, and vice versa and this may be, as suggested by Lange et al. (1997) a general strategy for soil crust lichens. It is very clear, however, that this strategy has 
TABLE 3. Comparison of main ecophysiological parameters of Diploschistes diacapsis from arid lands in southern Utah and from semiarid SE Spain (Tabernas desert, Almería)

\begin{tabular}{lcc}
\hline Parameter & $\begin{array}{c}\text { Utah desert } \\
\text { (Lange } \text { et al. 1997) }\end{array}$ & $\begin{array}{c}\text { Almería badlands } \\
\text { present study }\end{array}$ \\
\hline $\mathrm{NP}$ max - area basis $\mu \mathrm{mol} \mathrm{CO}_{2} \mathrm{~m}^{-2} \mathrm{~s}^{-1}$ ) & $2 \cdot 5$ & $4 \cdot 1-5 \cdot 0$ \\
$\mathrm{NP}$ max - chlorophyll basis $\left(\mathrm{nmol} \mathrm{CO}_{2} \mathrm{mg}^{-1} \mathrm{Chl} \mathrm{s}^{-1}\right)$ & 18 & $2 \cdot 1-3 \cdot 6$ \\
Dark respiration-area basis $\left(\mu \mathrm{mol} \mathrm{m}^{-2} \mathrm{~s}^{-1}\right.$ ) & $1 \cdot 2$ & $3 \cdot 9-5 \cdot 1$ \\
Apparent quantum efficiency & $0 \cdot 015$ & $0 \cdot 005-0 \cdot 024$ \\
Chlorophyll content-area basis $\left(\mathrm{mg} \mathrm{m}^{-2}\right)$ & $210 \cdot 3$ & $1350-1780$ \\
MWC (mm rainfall equivalent) & $1 \cdot 60$ & $1 \cdot 12-1 \cdot 46$ \\
Optimal temperature for NP $\left({ }^{\circ} \mathrm{C}\right)$ & 20 & $21 \cdot 8-23 \cdot 8$ \\
Temperature to reach maximal GP $\left({ }^{\circ} \mathrm{C}\right)$ & 28 & $24 \cdot 8$ \\
NP compensation $\left(15^{\circ} \mathrm{C}, \mu \mathrm{mol} \mathrm{m}{ }^{-2} \mathrm{~s}^{-1}\right)$ & 100 & $103-151$ \\
\hline
\end{tabular}

reached its natural limit on the southern slopes of Almería. The much larger biomass in the shaded areas is an obvious indication that the higher NP of the sun form has not come close to compensating for the shorter active periods.

Lange et al. (1997) noted that soil crust lichens in southern Utah shared many features that would tend to allow them to be classified as 'sun' rather than 'shade' populations. Diploschistes diacapsis showed the same qualities here. Net photosynthesis was still not saturated at the highest PPFR used in the experiments $\left(1200 \mu \mathrm{mol} \mathrm{m} \mathrm{m}^{-2} \mathrm{~s}^{-1}\right)$ and light compensation points were high, reaching around $200 \mu \mathrm{mol} \mathrm{m} \mathrm{m}^{-2} \mathrm{~s}^{-1}$ at $30^{\circ} \mathrm{C}$. Temperature optima for NP and GP were also high in both studies $\left(22-28^{\circ} \mathrm{C}\right)$, similar values to those reported for Squamarina lentigera (Lange \& Green 2004). This might suggest that photosynthesis takes place under warm conditions but against this is the obvious superior productivity, at least in visible biomass, at the shaded site. In contrast, the Almería D. diacapsis have unexpectedly high chlorophyll contents, about 8 times that of the Utah lichens, a feature that would normally suggest a shadeadapted lichen. This could be an indicator that photosynthesis is highly effective in the early morning when light levels are lower and when temperatures up to about $20^{\circ} \mathrm{C}$ were almost equally effective for NP.

Although D. diacapsis showed some level of adaptation to sites with different aspects, the lichen seems to have reached its adaptation limits at the Almería site where it is much less successful visually, on the sunnier, south-exposed slopes. However, it is becoming clear that the water relations and photosynthetic activity for soil crust lichens can be more complex than previously thought. Studies on other lichens have shown that small quantities of water from early morning dew and high humidity can be more important to the overall carbon balance of the lichen than periods when wetted by rain (Lange 2003). Evidence to provide answers to these questions will require lichen activity to be monitored in situ for a long period. This research is now in progress and we are monitoring thallus photosynthetic activity by means of chlorophyll fluorescence and the microclimatic conditions in both populations simultaneously. These data will provide us with a better understanding of the function of soil crust lichens in arid lands and their contribution to soil stabilization under the most unfavourable conditions.

This work forms part of the project REN2003-04570 funded by the Spanish Ministry of Science and Technology: "Precipitation Patterns and Living Crusts in Semi-Arid Mediterranean. Lichen crusts as possible sensor for Climate Change". We thank the Viciana brothers, the owners of the land, for allowing research on the vegetation in the badlands.

\section{REFERENCES}

Alexander, R. W. \& Calvo, A. (1990) The influence of lichens on slope processes in some Spanish 
badlands. In Vegetation and Erosion (J. B. Thornes, ed.): 385-398. Chichester: John Wiley.

Alexander, R. W., Harvey, A. M., Calvo, A., James, P. A. \& Cerda, A. (1994) Natural stabilisation mechanisms on badland slopes: Tabernas, Almería, Spain. In Environmental Change in Drylands: Biogeographical and Geomorphological Perspectives (A. C. Millington \& K. Pye, eds): 85-111. Chichester: John Wiley \& Sons.

Barnes, J. D., Balaguer, L., Manrique, E., Elvira, S. \& Davison, A. W. (1992) A reappraisal of the use of DMSO for the extraction and determination of chlorophyll $a$ and $b$ in lichens and higher plants. Environmental and Experimental Botany 32: 85-100.

Belnap, J. \& Lange, O. L. (eds) (2003) Biological Soil Crusts: Structure, Function, and Management. Ecological Studies 150. Revised 2nd printing. Berlin: Springer-Verlag

Belnap, J., Büdel, B. \& Lange, O. L. (2003) Biological soil crusts: characteristics and distribution. In Biological Soil Crusts: Structure, Function, and Management (J. Belnap \& O. L. Lange, eds): 3-30. Revised 2nd printing. Berlin: Springer-Verlag.

Calvo-Cases, A., Harvey, A. M., Paya-Serrano, J. \& Alexander, R. W. (1991) Response of the badland surfaces in the southeast Spain to simulated rainfall. Cuaternario y Geomorfología 5: 3-14.

George, D. B., Roundy, B. A., St. Clair, L. L., Johansen, J. R., Shaalje, G. B. \& Webb, B. L. (2003) The effects of microbiotic soil crusts on soil water loss. Arid Land Research and Management 17: 113-125.

Gutiérrez, L. \& Casares, M. (1994) Flora liquénica de los yesos miocénicos de la provoncia de Almería (España). Candollea 48: 343-358.

Lange, O. L. (2003) Photosynthetic productivity of the epilithic lichen Lecanora muralis: long-term field monitoring of $\mathrm{CO}_{2}$ exchange and its physiological interpretation. II. Diel and seasonal patterns of net photosynthesis and respiration. Flora 198: 55-70

Lange, O. L. \& Green, T. G. A. (2004) Photosynthetic performance of the squamulose soil-crust lichen Squamarina lentigera: laboratory measurements and long-term monitoring of $\mathrm{CO}_{2}$ exchange in the field. Bibliotheca Lichenologica 88: 363-390.
Lange, O. L., Belnap, J., Reichenberg, H. \& Meyer, A. (1997) Photosynthesis of green algal soil crust lichens from arid lands in southern Utah, USA: role of water content on light and temperature responses of $\mathrm{CO}_{2}$ exchange. Flora 192: 1-15.

Larcher, W. (1995) Physiological Plant Ecology. 3rd edn. Berlin: Springer Verlag.

Lázaro, R., Alexander R. W. \& Puigdefábregas, J. (2000) Cover distribution patterns of lichens, annuals and schrubs in the Tabernas Desert, Almería, Spain. In Vegetation Mapping: from Patch to Planet (R. W. Alexander \& A. C. Millington, eds): 19-40. Chichester: John Wiley \& Sons.

Lázaro, R., Rodrigo, F. S., Gutiérrez, L., Domingo, F. \& Puigdefábregas, J. (2001) Analysis of a thirty year rainfall record (1967-1997) from semi-arid SE Spain: a plant ecological perspective. Fournal of Arid Environments 48: 373-395.

Llimona, X. (1973) Las Comunidades de líquenes de los yesos de España. PhD thesis, University of Barcelona.

Lumbsch, H. T. (1988) The identity of Diploschistes gypsaceus. Lichenologist 20: 19-24.

Mottershead, D. \& Lucas, G. (2000) The role of lichens in inhibiting erosion of a soluble rock. Lichenologist 32: 601-609.

Pintado, A., Valladares, F. \& Sancho, L. G. (1997) Exploring phenotypic plasticity in the lichen Ramalina capitata: morphology, water relations and chlorophyll content in north- and south-facing populations. Annals of Botany 80: 345-353.

Solé-Benet, A., Calvo, A., Cerdá, A., Lázaro, R., Pini, R. \& Barbero, J. (1997) Influences of micro-relief patterns and plant cover on runoff related processes in badlands from Tabernas (SE Spain). Catena 31: 23-38.

Souza-Egipsy, V., Ascaso, C. \& Sancho, L.G. (2002) Water distribution within terricolous lichens revealed by scanning electron microscopy and its relevance in soil crust ecology. Mycological Research 106: $1367-1374$.

St. Clair, L. L. \& Johansen, J. R. (1993) Introduction to the symposium on soil crust communities. Great Basin Naturalist 53: 1-4. 